\title{
Bamboo Fibers, Fabrication of Bamboo Fiber reinforced Composites, and their Mechanical Properties- A Review
}

\author{
Martijanti $^{1,2}$, Sutarno ${ }^{3}$, Ariadne L. Juwono ${ }^{1 *}$ \\ ${ }^{1}$ Department of Physics, Faculty of Mathematics and Natural Sciences, Universitas Indonesia (UI), Depok, 16424, Indonesia \\ ${ }^{2}$ Department of Mechanical Engineering, Faculty of Manufacturing Technology, Jenderal Achmad Yani Universtity (Unjani), \\ Cimahi, Indonesia. \\ ${ }^{3}$ Department of Metallurgy Engineering, Faculty of Manufacturing Technology, Jenderal Achmad Yani University (Unjani), \\ Cimahi, Indonesia. \\ * Corresponding author: ariadne.laksmidevi@ui.ac.id
}

\begin{abstract}
Bamboo fiber is a natural fiber that is easily degraded by microbes and potentially becomes an alternative fiber in the future due to its availability, which is abundantly cheap, and grows throughout the year and also isn't affected by the season. The application of bamboo fiber is a solution for environmental issues and a business prospect of synthetic fibers that are expected to decrease in line with petroleum. This study presents result of the studies of various types of bamboo, fiber extraction process both mechanically and chemically, composite fabrication based on various matrices, characterization carried out to reveal performance related to the requirements of various applications, weaknesses and improvements. Based on the result of this study, the researchers obtain information related to development and research status of bamboo fiber along with the application and weakness, as well as opportunity to make some improvements.
\end{abstract}

Key words: Bamboo fiber, fiber extraction process, type of matrix, mechanical properties, composite fabrication.

\section{INTRODUCTION}

There are so many natural fiber producer resources, especially from plants namely hemp, rice straw, wood, rice husks, wheat, barley, wheat, rye, sugar cane (sugar and bamboo), grass, reeds, kenaf, hemp, oil palm empty fruit, bunches, sisal, coir, water hyacinth, pennywort, cottonwood, mulberry paper, raffia, banana fiber, pineapple leaf fiber and papyrus [1].

Bamboo can naturally grow and develop in 4 continents, namely Asia (China, India, Thailand, Bangladesh, Cambodia, Vietnam, Japan, Indonesia, Malaysia, Philippines, Korea, and Sri Lanka), Africa (Mozambique, Sudan, and Madagascar), America (Mexico, Guatemala, Costa Rica, Nicaragua, Honduras, Venezuela, and Brazil), and Australia. Bamboo can be found at $32^{\circ}$ S.L. $-46^{\circ}$ N.L. Bamboo generally thrives in tropical or sub-tropical areas with temperatures between $20-30^{\circ}$ C. But there are several types of bamboo that can survive in the temperatures up to 40-50 $0^{\circ}$., (oxytenanthera abyssinica bamboo in Africa) can even survive in hot and cold weather below $0^{\circ} \mathrm{C}$ (phyllostachys mitis, which mostly grows at altitudes between 100-800 meters), but it can also be found at altitudes above 3000 meters $[2,3]$.

As one of the fiber producers, bamboo is estimated to have more than 1,250 species with world production reaching $10 \times 106$ tons and is the third largest production after wood and cotton. Bamboo fiber price reaches USD0.5-1.0/kg. Indonesia is the second largest exporter, with a value of USD269 million after China valuing USD1,034 million. Bamboo production in Asian countries reaches $65 \%$, followed by the U.S. with $28 \%$ and Africa 7\%. [4]. On the other hand, bamboo importers are Japan worth USD194 million, the U.S worth USD254 million and Europe USD230 million [4].

Bamboo belongs to Graminaeae family, Bambusoideae sub-family, from the Bambuceae tribe. Bamboo is a plant whose stem is reed-shaped, broad, has nodes, hollow, branches, spreading and also has a prominent reed cycle [5]. Furthermore, the diameter of a bamboo stem depends on the species and the environment in which it grows, with values varying between $0.5-20 \mathrm{~cm}$. The diameter of mature stems can be recognized from the diameter of young bamboo shoots. Bamboo is divided into small parts by lateral tissue, namely nodes and internodes section. Bamboo stems consist of parenchyma cells, fibers, and vessels [6].

In Indonesia, bamboo can be found in the lowlands to the mountains with an altitude of around $3000 \mathrm{~m}$ above sea level, especially in Java, Bali, South Sulawesi and Sumatera [7]. Bamboo, in Indonesia, also consists of 143 types, with 60 varieties that are expected to grow in Java. Bamboo stems are ready to be harvested at 1-2 years old, suitable for pulp and handicraft production. Meanwhile at 3 years old, bamboo stems are generally suitable to be harvested for building 
materials, furniture and other industries. The results of the study found that $80 \%$ of bamboo in Indonesia are used for construction (including furniture), $10 \%$ for packaging materials, $5 \%$ for handicraft raw materials (small industries), and $5 \%$ for agricultural facilities [8].

Bamboo is environmentally friendly (does not consume too much energy) as well as wood, its strain energy is equivalent to steel and its resistance to deflection and arches is equivalent to wood, especially when earthquake happened. Bamboo has better mechanical properties compared to brick, concrete, wood, and even steel. Bamboo is obtained from natural resources, a result of cultivation activities carried out by humans through proliferation of various methods, both generatively through bamboo seeds and propagation, as well as in term of vegetative process through rhizomes, stem and branch cuttings, stem stumps in bamboo clumps, and plant tissue isolation method. Harvesting of bamboo depends on age, season, and the part used (stems or bamboo shoots). Harvesting period for stem production is carried out during the dry season or at the beginning of the dry season to prevent bamboo from borer attack. During the dry season, the amount starch is also very low $[6,8]$. The properties that determine the use of bamboo are stem dimension, stem sharpness, stem straightness, branch size and distribution, length of stem segments, shape and proportion of segments, relative proportions of existing tissues, density and strength of wood, and resistance to fungi and insect attack [9].

The average production of Apus Bamboo in East Java is 7.5 tons/ha/year. The results of a study conducted by the UGM Forestry Faculty team showed an estimate of bamboo potential in the Special Region of Yogyakarta reaching 2,900,000 bamboo plants/year, West Java 14,130,000 bamboo plants/year, Central Java 24,730,000 bamboo plants/year, and East Java 29,950,000 bamboo plants/year [8]. Figure 1 shows that similar to acacia plants, bamboo plants are planted more in Java, reaching 29.14 million clumps or around $76.83 \%$ of the total population of Indonesian bamboo, while the remaining around 8.79 million clumps $(23,17 \%)$ are outside of Java. Bamboo plants in Java are concentrated in three consecutive provinces, namely West Java (28.09\%), Central Java (21.59\%), and East Java (19.38\%), while outside Java in South Sulawesi Province (3.69\%) [10].

Bamboo is a fast growing plant and is able to absorb carbon dioxide in the air. Bamboo can be harvested at 3-4 years old. Bamboo belongs to a group of grass species called Bambu soideae and compared to other plant fibers, bamboo has several advantages, namely low cost, light specific gravity, high growth rate, good strength and stiffness value $[11,12]$. Bamboo can be used for technical materials in intact condition or in the form of strips and fiber [13]. Bamboo fiber consists of cellulose, hemicellulose and lignin. Cellulose and hemicellulose level in the form of holocellulose can be more than 50\% [14]. Bamboo fiber mechanically has a high tensile strength (140-800 MPa), and a high modulus of elasticity (33 $\mathrm{GPa})$ with a low density of $0.6-0.8 \mathrm{~g} / \mathrm{cm} 3$. Specific characteristics of bamboo fibers such as low specific gravity, strength and specific stiffness can be compared with glass fibers $[15,16]$. Table 1 shows the comparison of the mechanical properties characteristics of bamboo fiber and glass fiber and Table 2 Comparison of the characteristics of bamboo fiber and glass fiber.

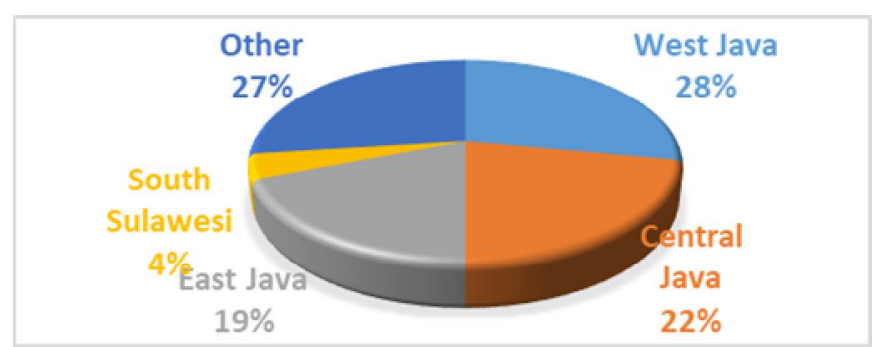

Figure 1: Bamboo Mapping in Indonesia

The purpose of this study is to map the development and progress of research covering, but not limited to

1. Types of bamboo fibers for composite materials,

2. Parameters of processing extraction and characterization of fibers

3. Types of resins, fiber ratios and matrices, orientation of longitudinal, random, woven fibers, and the shape of the laminae,

4. Parameters of the composite processing such as temperature and pressure, the selection of the fiber shape, the volume fraction

5. The mechanical and physical characteristics of the composite material.

\section{METHODOLOGY}

Methodology is a framework for thinking related to input-process-output and their characteristics based on standard requirements. Methodology of mapping journal review will be carried out as shown in Figure 2.

\section{RESULTS}

Based on the journal mapping, it was obtained

1. The status of the research and development of the type and parameters of the extraction process and the characteristics of the mechanical properties of bamboo fiber,

2. The type of matrix used for the fabrication of bamboo fiber composites and its mechanical and physical properties.

The results of this mapping will be used as a reference for designing the next research that includes extraction process parameters and types of fiber characteristics and composite fabrication process parameters and types of testing. 
Martijanti et al., International Journal of Emerging Trends in Engineering Research, 8(6), June 2020, 2346 - 2359

Table 1: Comparison of mechanical properties of bamboo fiber composite and glass fiber

\begin{tabular}{|c|c|c|c|c|c|c|c|c|c|}
\hline No & Fiber & $\begin{array}{l}\text { Volume } \\
\text { Fraction } \\
\text { (vf: \%) }\end{array}$ & $\begin{array}{c}\text { Tensile } \\
\text { strength } \\
(\mathrm{MPa})\end{array}$ & $\begin{array}{c}\text { Tensile } \\
\text { Modulus } \\
(\mathrm{GPa})\end{array}$ & $\begin{array}{c}\text { Elongation } \\
(\%)\end{array}$ & $\begin{array}{c}\text { Flexural } \\
\text { strength } \\
(\mathrm{MPa})\end{array}$ & $\begin{array}{c}\text { Flexural } \\
\text { modulus } \\
(\mathrm{GPa})\end{array}$ & Density (g/cm3) & Ref \\
\hline 1 & $\mathrm{BF}$ & & $500-575$ & $27-40$ & $1.9-3.2$ & $100-150$ & $10-13$ & $1.2-1.5$ & [4] \\
\hline 2 & GF & & $124-150$ & $7-10$ & $2.5-4.8$ & $110-150$ & $5-9$ & $2.35-2.5$ & \\
\hline \multicolumn{10}{|c|}{ Composite Materials } \\
\hline 3 & BF+Epoxy & 65 & $87-165$ & $3-15$ & $1.7-2.2$ & $107-140$ & $10-12$ & $1.16-1.25$ & [14] \\
\hline 4 & GF+Epoxy & 65 & $180-220$ & $5-10$ & $2.7-3.5$ & $195-220$ & $7-12$ & $1.96-2.02$ & [4] \\
\hline
\end{tabular}

Table 2: Comparison of the characteristics of bamboo fiber and glass fiber

\begin{tabular}{lll}
\hline Characteristics & Bamboo Fiber & Glass Fiber \\
\hline Density & Low & Higher than bamboo \\
Price & Low & Higher than bamboo \\
Disposal & Biodegradable & Non-Biodegradable \\
CO2 Absorption & Yes & No. \\
Recyclability & Yes & No. \\
Renewability & Yes & No. \\
Energy for extraction & Low & High \\
\hline
\end{tabular}

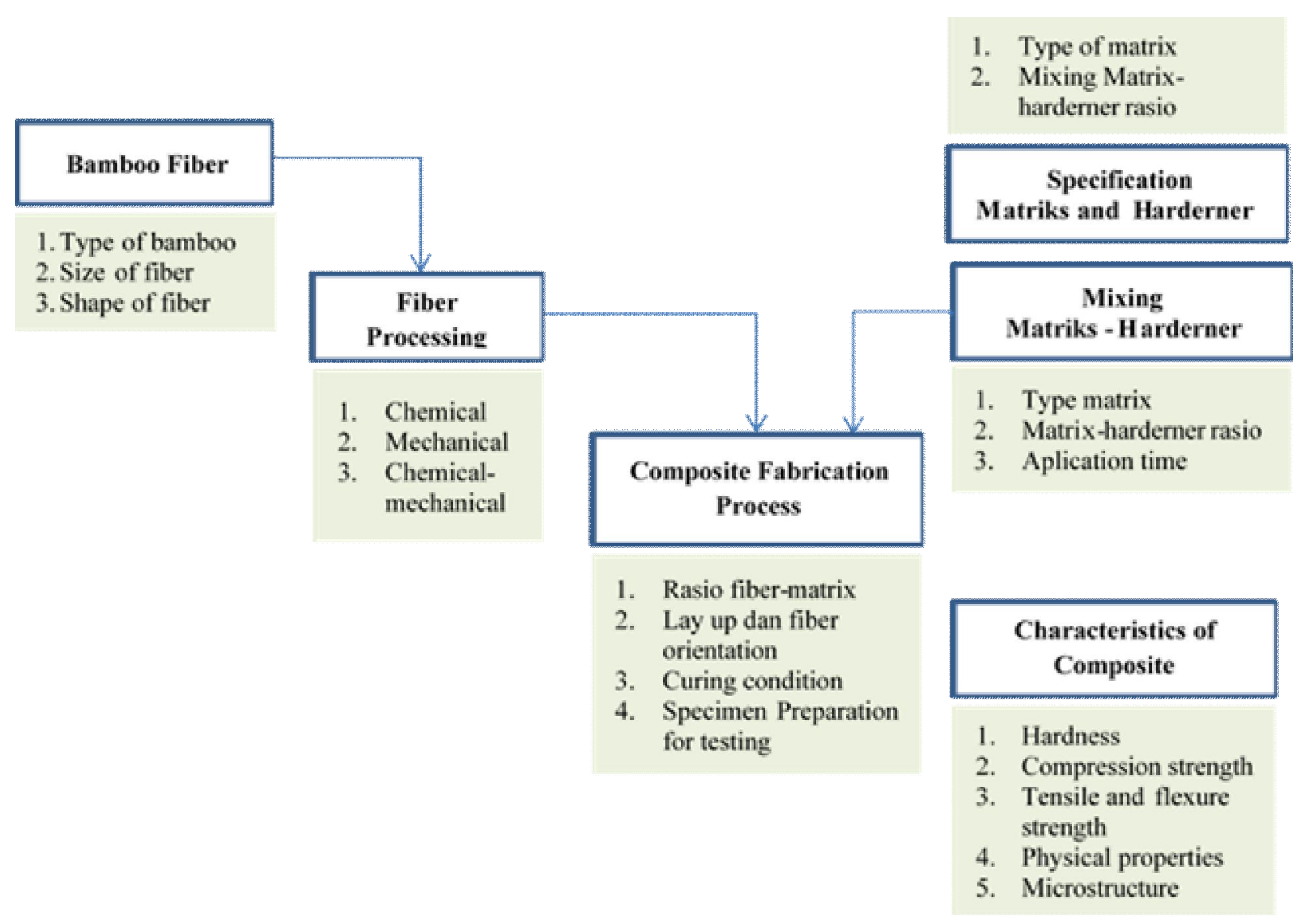

Figure 2: Methodology of The Mapping of Journal Review of the Bamboo Fiber-Reinforced Composite Materials 
Martijanti et al., International Journal of Emerging Trends in Engineering Research, 8(6), June 2020, 2346 - 2359

Table 3: Process of Bamboo Fiber Processing

\begin{tabular}{lll}
\hline Chemical Methods & Mechanical Methods & $\begin{array}{l}\text { Chemical and Mechanical } \\
\text { Methods }\end{array}$ \\
\hline Chemical retting [17,18]. & Steam Explosion Method [17,23,24,[25,26] & CMT [32]. \\
Alkali [19,20]. & Crushing [17,25]. & RMT [32]. \\
Acid Retting [21,22]. & Grinding [27,28]. & \\
& Rolling Mill [11,29]. \\
& Retting [30,31]. & \\
\hline
\end{tabular}

\subsection{Bamboo Fiber Processing Method}

Bamboo fiber processing methods can be carried out through three methods. Those are chemical processing methods, mechanical processing, and combination of chemical and mechanical processing methods. Chemical extraction methods such as Chemical Retting and Alkaline or Acid Retting are used to remove or reduce the lignin element from the fibers. This chemical extraction method also affects other elements contained in fiber such as pectin and hemicellulose $[17,22,32]$.

Meanwhile, fiber processing processes with mechanical methods are Steam Explosion, Crushing, Grinding, Rolling Mill and Retting. This method is used to produce fibers that can be implemented in various industries and is used as fiber raw materials in composite materials. The third method is a combination of chemical and mechanical processes. The process can be seen in the Table 3.

\subsection{Chemical Retting}

Chemical Assisted Natural (CAN) is a retting process used by the researchers to reduce lignin and water level in the fiber. The bamboo culm is cut longitudinally into thin sheets. Manually separated fibers are soaked in $\mathrm{Zn}$ (NO3) 2 solution with concentrations of $1 \%, 2 \%$ and $3 \%$ for the ratio of material is $1: 20$ to the solvent. This fiber is soaked at a temperature of $40^{\circ} \mathrm{C}$ for 116 hours in neutral $\mathrm{pH}$ and stored in an incubator BOD and then the fiber is boiled in water for 1 hour. This procedure can remove the level of lignin better than alkaline and acid retting process, but fiber has a high moisture [17].

In another study, bamboo culms are cut into thin sheets with a thickness of $2 \mathrm{~cm}$ and then put in the oven at a temperature of $150^{\circ} \mathrm{C}$ for 30 minutes. Thin bamboo sheets are soaked in water for 24 hours at $60^{\circ} \mathrm{C}$ and dried in the open air. The next process, the fiber is cooked with $2 \%$ sodium silicate, $2 \%$ sodium sulphite, $2 \%$ sodium polyphosphate and $0.5 \% \mathrm{NaOH}$ $(\mathrm{w} / \mathrm{v})$ at $100^{\circ} \mathrm{C}$ for 60 minutes with a ratio of solvent to fiber is 1: 20. The fiber is then washed with hot water and treated with $0.04 \%$ xylanase and $0.5 \%$ diethylene triamine penta acetic acid at $70^{\circ} \mathrm{C}$ with a $\mathrm{pH}$ of 6.5 for 60 minutes. The fiber is then cooked at $100^{\circ} \mathrm{C}$ for 60 minutes with the same procedure, but with $0.7 \% \mathrm{NaOH}$. The fiber is then put into a plastic bag (polyethylene type) and undergoes bleaching process with $0.5 \%$ sodium silicate, $4 \% \mathrm{H} 2 \mathrm{O} 2$ and $0.2 \%$ sodium hydroxide for 50 minutes. The ratio of the solvent is maintained at 1:20 to fiber and $\mathrm{pH}$ at 10.5. And the last, the fiber is added with $0.5 \%$ sulfuric acid for 10 minutes and an emulsification process for 5 days, to obtain smooth bamboo fibers. This study finds that fibers which have microfibrils with small orientation angles, and compared to hemp and cotton fibers, this type of fiber is suitable for reinforcement fibers in composites [18].

\subsection{Alkaline or Acid Retting}

\section{Alkali}

Alkaline process is applied to bamboo that has been cut into strips, and then soaked in $1.5 \mathrm{~N} \mathrm{NaOh}$ in a steel stainless bowl at temperature of $70^{\circ} \mathrm{C}$ for 5 hours. Then the alkali bamboo strips are pressed using a press machine to obtain bamboo fibers, after which they are washed with water and dried in an oven. With this extraction method the damage to the fiber cross section decreases [19]. Other study influencing the cellulose and non-cellulosic portions of bamboo fiber is chip-sized bamboo strips are soaked in a $4 \% \mathrm{NaOH}$ solution for 2 hours. In term of fiber extracts in the form of pulp, this procedure is repeated several times at a certain pressure. However, the problem with this extraction procedure is that it produces bundles of large fibers [22]. In another study, small bamboo strips are soaked in $1 \mathrm{~N}$ sodium hydroxide solution for 72 hours to produce fiber [22], Other research for gigantochloa apus with the alkaline treatment process will increase the value of tensile strength and bending strength compared to fibers that do not go through the stages of the alkaline treatment process. The value of tensile and bending strength increases by $46 \%$.

\section{Acid Retting}

Trifluoroacetic acid (TFA) and alkali solutions that are some of the solutions used to extract fibers and lignin elements will dissolve under acidic and basic conditions. The researchers show that there is still a large amount of lignin in the middle of the fiber that must be removed. The results show that in the alkaline procedure there is remaining lignin in the middle and and most of them will be removed through TFA process [33]. Interfacial bonding and surface adhesion of composites to the alkaline process has improved better than other methods [21]; [22]. 


\subsection{Steam Explosion Method}

This Method is a low energy consumption method and produces pulp. In this process, the separation occurs in plant cell walls. This method is the right process to separate lignin from the plant surface, but produces rigid and opaque fibers [34]. In another study, fibers are separated from the bundles by using a sifter machine, producing fibers with a diameter of $125-210 \mu \mathrm{m}$. The fiber is then dried at $120^{\circ} \mathrm{C}$ for 2 hours. This method is a very effective process for removing lignin from wood and bamboo fibers [23]. Steam explosion process is carried out for raw bamboo, which has been cut into strips and put into an autoclave at $175^{\circ} \mathrm{C}$ for 60 minutes at a pressure of $0.7-0.8 \mathrm{MPa}$. The steam is, then, released immediately in every 5 minutes for nine times. Next, the fiber is washed with hot water at $90-95{ }^{\circ} \mathrm{C}$ and then being mixed with soap and is dried in an oven at $105^{\circ} \mathrm{C}$ for 24 hours. It is because most of the lignin on the surface of the fiber will lead to decreasing adhesion between the resin and fiber [15]. In the process of steam explosion, the cell wall of the fiber breaks and produces fine bamboo fibers. In other studies, lignin removal process is carried out through the isocyanate silane method.

From the results, it is found that the bamboo fiber extracted by steam explosion has a higher tensile strength than the isocyanate silane treatment process [24]. The tensile strength of the fiber that is reinforced with polymer material has decreased due to improper fiber treatment / extraction, which results in weak bonding of the fiber interface with the matrix. The proper surface treatment process of the fibers will be needed to achieve a good adhesion bonding between the fiber and the matrix [25]. Another study uses 0.25 bamboo fiber which has been prepared and put in autoclave.

The degumming process in the autoclave is carried out with a composition of $10 \mathrm{ml}$ of non-ionic rucogen surfactant FWK $50,10 \% \mathrm{NaOH}$ solution with a variation of 400 and $800 \mathrm{~mL}$, and water up to $4 \mathrm{~L}$. Bamboo is processed in an autoclave at a temperature of $90^{\circ} \mathrm{C}$ and a pressure of $0.9-1.0 \mathrm{~kg} / \mathrm{cm} 2$ for 60 minutes. Next, bamboo is washed with water for 3-4 times until the water looks pretty clear. As the result, bundles of bamboo fiber obtained from the experiment will contain lower lignin and hemicellulose elements in bamboo that has been processed through autoclave process with $\mathrm{NaOH}$ solution. This will increase adhesion bonding between the fiber and matrices [26].

The Steam Explosion method carried out for the result of fiber tensile strength experiment shows that bamboo fibers (bundles) have a certain strength that is sufficient, which is equivalent to conventional glass fibers. The tensile and modulus strength of the fiber-reinforced composite material resulting from steam explosion process using a Polypropylene matrix increases by $15 \%$ and $30 \%$, compared to composites using fibers whose processing is carried out mechanically. Steam explosion technique is an effective method for extracting bamboo fibers to strengthen thermoplastics [23].

\subsection{Crushing}

In this procedure, raw bamboo is cut into small pieces using a roll crusher. Then the rough fiber is obtained from small pieces of bamboo using a pin-roller. Then the fibers are cooked at a temperature of $90^{\circ} \mathrm{C}$ for 10 hours to remove fat and then dried with a rotary dryer and put in a dehydrator [17].

The main problem with this process is that it produces short fibers, and the next mechanical processing will produce powder [25].

\subsection{Grinding}

In this procedure, bamboo culms without nodes are then soaked in water for 24 hours. Then the strips are cut into smaller pieces with a knife. The strip passes through the extruder and the bamboo strip is cut into thin bamboo sheets. This small bamboo chip is refined using a high speed blender for 30 minutes to get bamboo fibers. Using several filters with various holes, the fibers are separated by size. The extracted fibers are finally dried in an oven at $10^{\circ} \mathrm{C}$ for 72 hours [27]. Fiber length has an effect on the strength of the tensile load. Thus, it increases the modulus of the composite materials. Some researchers use the same method for extracting bamboo fibers, as well as rheological behavior and composite morphology of bamboo fibers [35]. This method has also been used in studies to obtain bamboo particles / fibers in nano size [28].

\subsection{Rolling Mill}

In this procedure, bamboo culms are cut into slices with a thickness of $1 \mathrm{~mm}$. To facilitate the separation of fibers from the slices, the strips are soaked in water for 1 hour. The bamboo strip is rolled in a low pressure and speed. The rolled strips are soaked for 30 minutes in water and then the fibers are separated using a razor. Then, the fibers are dried under the sun for 2 weeks and their length ranges from $220-270 \mathrm{~mm}$ [11]. In another study, to produce fiber extraction, bamboo strips are cut from bamboo culm and pressed between two pairs of cylindrical steel and without being soaked in water [29]. Meanwhile in another study, bamboo strips are sliced through steaming process and soaked in water to soften the lignin and fibers and then a roll process is carried out, resulting in fiber extraction with lengths ranging from 30 to $60 \mathrm{~cm}$.

\subsection{Retting}

In this procedure, bamboo culm is peeled to get the strips. The bundles of strips are kept in water for three days. The strip is beaten with a hammer, then the bamboo is brushed [30]. In this method, the scraping process has a strong effect on the quality of the fiber and reduces damage to the fiber. 
Martijanti et al., International Journal of Emerging Trends in Engineering Research, 8(6), June 2020, 2346 - 2359

Table 4: Comparison of mechanical and physical properties for bamboo fiber characteristics with various bamboo fiber extraction treatments

\begin{tabular}{|c|c|c|c|c|c|c|c|}
\hline Fiber & $\begin{array}{l}\text { Fiber processing } \\
\text { process }\end{array}$ & $\begin{array}{l}\text { Tensile strength } \\
\text { (MPa) }\end{array}$ & $\begin{array}{l}\text { Young's modulus } \\
\text { (GPa) }\end{array}$ & $\begin{array}{c}\text { Fiber Diameter } \\
\qquad(\mu \mathrm{m})\end{array}$ & $\begin{array}{l}\text { Fiber Length } \\
\quad(\mathbf{m m})\end{array}$ & $\begin{array}{l}\text { Density } \\
(\mathrm{g} / \mathrm{cm} 3)\end{array}$ & $\begin{array}{c}\text { Reference } \\
\text { s }\end{array}$ \\
\hline \multirow[t]{13}{*}{ Bamboo } & Steam explosion & $441 \pm 220$ & $36 \pm 13$ & $15-210$ & - & - & [16]. \\
\hline & Steam explosion & 383 & 28 & & 1440 & & [19]. \\
\hline & Steam explosion & 516 & 17 & & & & [16]. \\
\hline & Crushing & 420 & 38 & $262 \pm 160$ & - & - & [15]. \\
\hline & Grinding & $450-800$ & $18-30$ & - & - & 1.4 & [16]. \\
\hline & Rolling mill & 270 & - & $100-600$ & $220-270$ & - & [16]. \\
\hline & Retting & 503 & 35.9 & - & - & 0.91 & [30]. \\
\hline & Chemical & 329 & 22 & & 1356 & & [19]. \\
\hline & Chemical & 450 & 18 & 270 & 10 & 1.3 & \\
\hline & Alkaline & 419 & 30 & - & 1643 & - & [19]. \\
\hline & $\begin{array}{l}\text { Alkaline ( } 5 \% \\
\mathrm{NaOH} \text { for } 2 \text { hours) }\end{array}$ & 420 & - & - & - & - & \\
\hline & $\begin{array}{l}\text { Chemical }+ \\
\text { Compression }\end{array}$ & $645-1000$ & - & $50-400$ & $>10$ & $0.8-0.9$ & [32]. \\
\hline & $\begin{array}{l}\text { Chemical } \\
+ \text { Roller mill }\end{array}$ & $370-480$ & - & $50-100$ & $120-170$ & - & [32]. \\
\hline
\end{tabular}

In another study, bamboo is merely cut into several longitudinal sections without removing the node and epidermis. The bamboo strip is then cleaned with running water and fermented in water at room temperature for 2 months. Two types of Retting processes, aerobic and anaerobic, are used to produce fiber bundles, single fibers and long fibers [31].

\subsection{Combination of fiber processing through mechanical and chemical process}

Usually after alkaline and chemical treatment, compression moulding technique (CMT) and roller mill technique (RMT) are used to extract fibers. In a study, bamboo strips that have been undergone chemical treatment are placed in two flat plates with a pressure of under 10 ton using CMT.

In order to separate good quality of fibers, thickness and pressure time are important factors to consider. At RMT, two rollers, one fixed roller and the other roller are rotated, are used and bamboo strips are inserted between the two rollers.
The compression molding technique (CMT) and roller mill technique (RMT) processes combined with chemical treatment will result in the extraction of fibers from bamboo strips [32]. The results of the processing of fiber on bamboo will affect the mechanical and physical properties of bamboo fibers, to see the comparative data from bamboo fibers as the effect of fiber treatments (chemical, mechanical and a combination of both) can be seen in Table 4 .

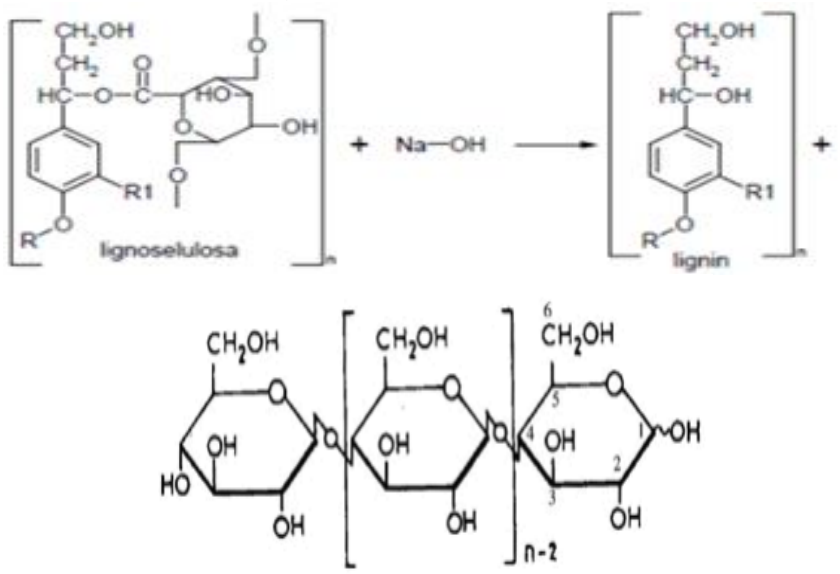

Figure 3: Lignocellulose reaction in $\mathrm{NaOH}$ solution [37]

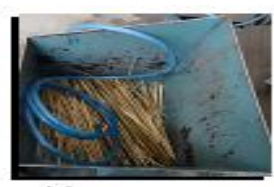

(a)

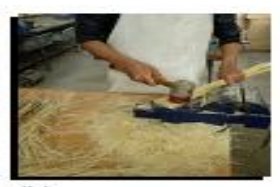

(b)

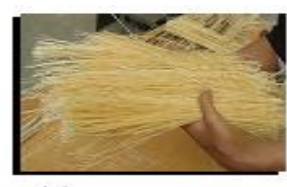

(c)



(d)

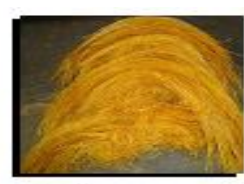

(e)

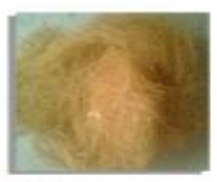

(f)

Figure 4: Extraction process and Alkaline treatment of bamboo fiber 
a) Bamboo strips immersed in water

b) Beating of bamboo strips with hammer

c) Final phase of manually extracted bamboo fiber

d) Bamboo fiber soaked by $\mathrm{NaOH}$

e) Bamboo fiber after soaked with sodium hydroxide

f) Alkaline treated and dried bamboo fiber

The alkali treatment of bamboo fibers is one of the chemical treatments that has been known to increase cellulose content through removal of hemicellulose and lignin, so that it will produce better mechanical properties of the fiber [36]. Based on figure 3, OH- (results of dissociation of $\mathrm{NaOH}$ into $\mathrm{Na}^{+}$and $\mathrm{OH}^{-}$) reacts with the $\mathrm{H}$ group on lignin, then forms $\mathrm{H}_{2} \mathrm{O}$. Cluster $\mathrm{O}$ forms free radicals and reacts with $\mathrm{C}$ to form epoxy rings (C-O-C). The reaction produces two separate benzene rings, where each ring has a reactive $\mathrm{O}$ group. This reactive group $\mathrm{O}$ reacts with $\mathrm{Na}^{+}$and dissolves in alkaline solutions so that lignin is removed when rinsed [31]. The process of alkalising the fiber can be seen in Figure 4.

\subsection{Characteristics of Bamboo-Reinforced Composite Materials}

The characteristics of bamboo-reinforced composite materials are influenced by composite production process which is determined by several parameters, including the choice of fiber type (natural fiber / synthesis fiber element) and matrix (thermoset, thermoplastic), fiber dimensions, fiber shape (fiber, powder, lamina), fiber orientation, and process parameters (temperature, pressure, time).

Studies that have been conducted on the parameters of composites production, namely research on the effect of lamina on the characteristics of composite materials has been conducted by several researchers, including the manufacture of LFRC (Laminate Fiber Reinforcement Composite) consisting of bamboo strips and epoxy in the form of layers 3 , 5 and 7, where each layer consists of unidirectional bamboo pieces [29].

From the LFRC test results by varying the amount of laminated composites, it can be obtained good LFRC test results in tensile tests (up to $243 \mathrm{MPa}$ ), compressive tests (up to $129 \mathrm{MPa}$ ) and flexural tests (up to $255 \mathrm{MPa}$ ). It proves that BFRC guarantees its use for construction and other purposes. Tensile, flexural and impact strength tests that are carried out in multidirectional, bidirectional, 5,7, and 9 bamboo-coated bamboo fibers and bamboo composite mats result in unidirectional composite that has a highest tensile strength up to $175.27 \mathrm{MPa}$, in a study conducted by [14].

Fabrication procedure to produce layered BFRC (Bamboo Fiber Reinforcement Composite) which combines bamboo slices that are obtained from bamboo stems using a slotted cutting machine and epoxy resin. Three configurations of layered bamboo composite using adhesives and butt joints are unidirectional configuration $\left[0^{\circ} / 0^{\circ} / 0^{\circ} / 0^{\circ} / 0^{\circ}\right]$, symmetrical configuration $\left[0^{\circ} / 45^{\circ} / 0^{\circ} / 45^{\circ} / 0^{\circ}\right]$ and cross-ply symmetrical configuration $\left[0^{\circ} / 90^{\circ} / 0^{\circ} / 90^{\circ} / 0\right.$ $\left.{ }^{\circ}\right]$. The specimens are tested for tensile, compressive and flexural properties, the results can be seen in table 3 , related to the relationship between lamina configuration to composite mechanical properties and optimal values obtained from unidirectional configuration $\left[0^{\circ} / / 0^{\circ} / / 0^{\circ} / / 0^{\circ} / 0^{\circ}\right]$. [38];[39]. Resume of the study on the effect of lamina and fiber orientation on the mechanical properties can be seen in table 5 .

Study on the characteristics of bamboo fiber-reinforced composite materials is focused on the granular size of bamboo particles $(20,40,60)$ mesh, bamboo fiber and PVC matrix (Polyvinyl Chloride) volume fraction with variations in fiber fraction $(30 \%, 40 \%, 50 \%)$, composite production process through a hot press with process parameters for $6 \mathrm{MPa}$ pressure, a pressure temperature of $448.15 \mathrm{~K}$ with a pressure time of 8 minutes. Combination of 40 mesh bamboo particle size with a fiber volume fraction used at $50 \%$ provides optimum strength values [40].

The process of composites production by varying the composition of fibers and matrices is done by [41], with the composition of $(30,50,70) \%$ of fibers with the highest value at $70 \%$ of bamboo fiber composition for a tensile strength of $265 \mathrm{MPa}$ and tensile modulus of $12.4 \mathrm{GPa}$, theoretically the greater the volume fraction used, the strength value will increase.

Other studies with the amount of fiber used in the process of composites production will have an effect on increasing the value of tensile strength, by varying $(0,4,8,12,16) \%$, the greater the volume fraction of the fibers used, then the composite tensile strength will increase [42]. Studies on the form of fiber used (fiber, powder) by varying the volume fraction $(0 \%, 50 \%$ and $100 \%)$ and bamboo fiber function as a fiber or matrices.

Temperature parameters vary $\left(160^{\circ} \mathrm{C}, 180^{\circ} \mathrm{C}, 200^{\circ} \mathrm{C}\right)$ at a pressure of $65 \mathrm{MPa}$, resulting in modulus of flexural value and tensile strength increasing in line with increasing fiber level [41]. The design of the composite production process is carried out by varying the volume of fiber fraction and combining natural fibers (bamboo) and alumina fibers. 
Martijanti et al., International Journal of Emerging Trends in Engineering Research, 8(6), June 2020, 2346 - 2359

The volume fraction for bamboo fibers $(15,30,45) \%$ and alumina fibers $(0,5,10,15) \%$ using Polyester matrices, leads in increasing composite tensile strength in line with the number of fiber fraction and alumina added to the polyester matrix [43]. Study on the effect of fiber volume fraction on the mechanical properties of bamboo fiber composite materials both pure bamboo fiber and the combination of 2 different types of fibers as well as has an effect on increasing strength along with the addition of fiber volume fraction [44]; [45]; [46]; [47]; [48]; [49]. Resume of study on volume fraction and fiber diameter, method of fabrication of Bamboo Fiber composites can be seen in table 6 . Composite fabrication by vacuum bagging system can be seen in Figure 5 .

Table 5: Resume of the study on the effect of lamina and fiber orientation on the mechanical properties of bamboo fiber-reinforced composite materials

\begin{tabular}{|c|c|c|c|c|c|c|}
\hline $\begin{array}{l}\text { Types of Fiber and } \\
\text { Matrices }\end{array}$ & $\begin{array}{l}\text { Amount of } \\
\text { Lamina/layer }\end{array}$ & Fiber Orientation & $\begin{array}{l}\text { Tensile Strength } \\
(\mathrm{MPa})\end{array}$ & $\begin{array}{c}\text { Pressure } \\
\text { Strength } \\
(\mathrm{MPa}) \\
\end{array}$ & $\begin{array}{c}\text { Flexural } \\
\text { strength } \\
(\mathrm{MPa}) \\
\end{array}$ & $\begin{array}{c}\text { Reference } \\
\text { s }\end{array}$ \\
\hline $\begin{array}{l}\text { Bamboo+Polyester }+5 \% \\
\text { Alkaline }\end{array}$ & 7 & - & 126 & - & 149 & \\
\hline $\begin{array}{l}\text { Bamboo+Epoxy }+5 \% \\
\text { Alkaline }\end{array}$ & 7 & - & 135 & - & 161 & {$[50]$} \\
\hline Bamboo +Epoxy & 7 & Strand mat & 233 & - & 194 & \\
\hline Bamboo + Polyester & 7 & Strand mat & 232 & - & 250 & \\
\hline Bamboo + Epoxy & 4 & $0 / 90$ & 43.47 & 52.56 & 60.97 & {$[51]$} \\
\hline Bamboo + Epoxy & $\begin{array}{l}3 \\
5 \\
7\end{array}$ & $\begin{array}{l}- \\
- \\
-\end{array}$ & $\begin{array}{l}243 \\
189 \\
178\end{array}$ & $\begin{array}{l}129 \\
59 \\
90\end{array}$ & $\begin{array}{l}255 \\
208 \\
245\end{array}$ & [29] \\
\hline & $\begin{array}{l}1 \\
5\end{array}$ & $\begin{array}{c}\text { Unidirectional }(0) \\
\text { Multidirectional }(0 / 45 / 90)\end{array}$ & $\begin{array}{c}175.27 \\
99.34\end{array}$ & - & $\begin{array}{l}151.83 \\
130.23\end{array}$ & \\
\hline Indian Bamboo +Araldite & 7 & $\begin{array}{l}\text { Multidirectional } \\
(0 / 30 / 60 / 90)\end{array}$ & 82.2 & - & 161,1 & [14] \\
\hline & 9 & $\begin{array}{c}\text { Multidirectional } \\
(0 / 22.5 / 45 / 67.5 / 90)\end{array}$ & 70.13 & - & 186.38 & \\
\hline Bamboo + Epoxy & 5 & $\begin{array}{c}{\left[0^{\circ} / 0^{\circ} / 0^{\circ} / 0^{\circ} / 0^{\circ}\right]} \\
{\left[0^{\circ} / 45^{\circ} / 0^{\circ} / 45^{\circ} / 0^{\circ}\right]} \\
{\left[0^{\circ} / 90^{\circ} / 0^{\circ} / 90^{\circ} / 0^{\circ}\right]}\end{array}$ & $\begin{array}{l}205 \\
188 \\
169\end{array}$ & $\begin{array}{l}80 \\
55 \\
66\end{array}$ & $\begin{array}{c}128.4 \\
68.28 \\
105.74\end{array}$ & {$[38]$} \\
\hline
\end{tabular}
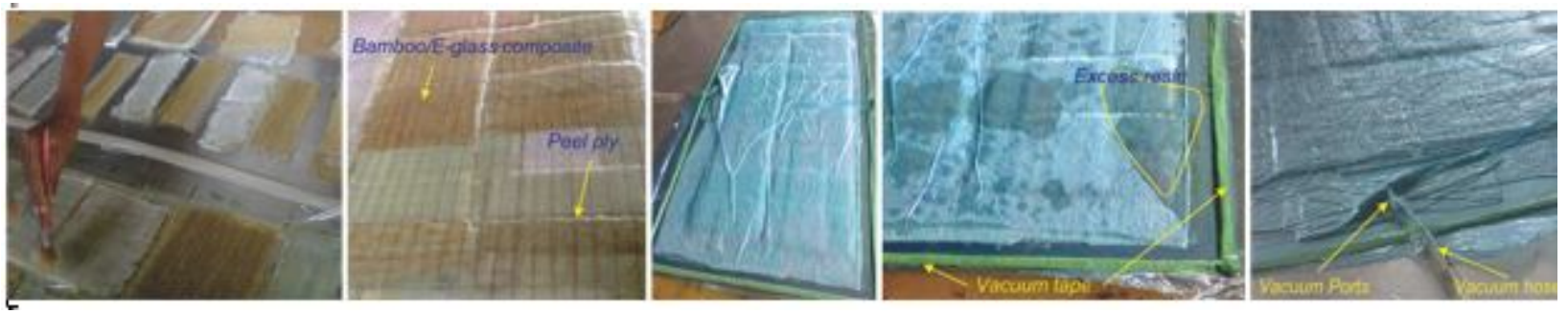

Figure 5: Composite fabrication by vacuum bagging system 
Martijanti et al., International Journal of Emerging Trends in Engineering Research, 8(6), June 2020, 2346 - 2359

Table 6: Resume of Study on Volume Fraction and Fiber diameter, Method of fabrication of Bamboo Fiber composite materials to Tensile Strength

\begin{tabular}{|c|c|c|c|c|c|}
\hline Type of Fiber & $\begin{array}{l}\text { Volume } \\
\text { Fraction of } \\
\text { Fiber }(\% \mathrm{wt})\end{array}$ & Fiber Diameter $(\mu \mathrm{m})$ & Methods & $\begin{array}{l}\text { Tensile } \\
\text { Strength (MPa) }\end{array}$ & References \\
\hline Bamboo & $50,60,70$ & $841,420,250$ & $\begin{array}{l}\text { Hot Press: } \\
\qquad \begin{array}{l}\text { Pressure }=6 \mathrm{MPa} \\
\text { Temperature }=448.15 \mathrm{~K} \\
\text { Time }=8 \text { minutes }\end{array}\end{array}$ & $1.53-7.50$ & {$[40]$} \\
\hline Bamboo & $10,20,30,40$ & - & $\begin{array}{l}\text { Hot Press: } \\
\text { Pressure }=3.2 \mathrm{MPa} \\
\text { Temperature }=190{ }^{\circ} \mathrm{C} \\
\text { Time }=30 \text { minutes }\end{array}$ & $13-17$ & \\
\hline Bamboo & $30,50,70$ & 100,300 & 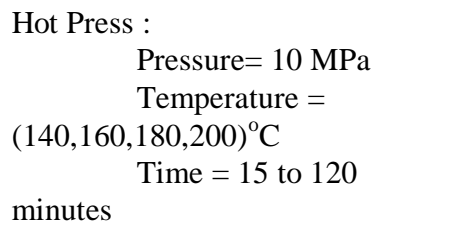 & $120.2-265.5$ & [41] \\
\hline Bamboo & $0,4,8,12,16$ & - & $\begin{array}{l}\text { Compression }- \text { Molding Process } \\
\text { Pressure }=0.05 \mathrm{MPa}(50 \\
\mathrm{kN}) \quad \begin{array}{l}\text { Temperature }=180{ }^{\circ} \mathrm{C} \\
\text { Time }=-\end{array}\end{array}$ & $8-30$ & {$[42]$} \\
\hline Bamboo & $0,50,100$ & $\begin{array}{c}50-100 \\
\text { (particles) } \\
100-300 \\
\text { (fibers) }\end{array}$ & $\begin{array}{l}\text { Hot Press : } \\
\text { Pressure }=65 \mathrm{MPa} \\
\text { Temperature }= \\
(160,180,200)^{\circ} \mathrm{C} \\
\text { Time }=-\end{array}$ & $25-169.9$ & {$[41]$} \\
\hline Bamboo & $15,30,45$ & $80-100$ & $\begin{array}{l}\text { Hot Press : } \\
\text { Pressure }=0.98 \mathrm{MPa} \\
\text { Temperature }=40^{\circ} \mathrm{C} \\
\text { Time }=24 \mathrm{~h}\end{array}$ & $7.241-18.767$ & [43] \\
\hline Bamboo & 0 to 100 & - & $\begin{array}{l}\text { Hand Lay Up + Compression - } \\
\text { Molding Process }\end{array}$ & $60-11$ & [44] \\
\hline Bamboo & $0,10,20,30$ & 35 & $\begin{array}{l}\text { Injection Molding } \\
\text { Temperatur } 160 \mathrm{oC}\end{array}$ & $27.98-41.35$ & {$[46]$} \\
\hline Bamboo & $30,40,50$ & $380-580$ & $\begin{array}{l}\text { Hot Press: } \\
\qquad \begin{array}{r}\text { Pressure }=0.80 \mathrm{MPa} \\
\text { Temperature }=185^{\circ} \mathrm{C}\end{array}\end{array}$ & $40-70$ & [47] \\
\hline Bamboo & $10,20,30,40,50$ & $175-250$ & $\begin{array}{l}\text { Hand Lay Up + Compression }- \\
\text { Molding Press : } \\
\text { Pressure }=0.05 \mathrm{MPa} \\
\text { Temperature }=80^{\circ} \mathrm{C} \\
\text { Time }=2 \text { hours }\end{array}$ & $30-120$ & [30] \\
\hline Bamboo & $30,40,50,60$ & $90-125$ & $\begin{array}{c}\text { Compression Moulding Press: } \\
\text { Pressure }=25 \text { Ton } \\
\text { Temperature }=160^{\circ} \mathrm{C} \\
\text { Time }=5 \text { minutes }\end{array}$ & $24.50-50.26$ & [17] \\
\hline Bamboo Fiber & 35,50 & $100-300$ & $\begin{array}{l}\text { Hand Lay Up + Compression - } \\
\text { Molding Press : } \\
\text { Pressure }=32 \mathrm{MPa}\end{array}$ & $70.13-175.27$ & \\
\hline $\begin{array}{l}\text { Laminated } \\
\text { Bamboo }\end{array}$ & $60,63,65,70$ & $100-300$ & $\begin{array}{l}\text { Hand Lay Up + Compression - } \\
\text { Molding Press : } \\
\text { Pressure }=32 \mathrm{MPa}\end{array}$ & $80.5-110.5$ & {$[14]$} \\
\hline
\end{tabular}

Note $=1$ kilonewton $/$ meter $^{2}\left[\mathrm{kN} / \mathrm{m}^{2}\right]=0.001$ megapascal $[\mathrm{MPa}], 1$ kilogram-force/centimeter ${ }^{2}=0.0980665$ megapascal 
Martijanti et al., International Journal of Emerging Trends in Engineering Research, 8(6), June 2020, 2346 - 2359

Table 7: Resumes of the study on the Effect of Matrix Type to Mechanical characteristics of Bamboo Fiber Composites

\begin{tabular}{|c|c|c|c|c|c|c|c|}
\hline Fiber & Type of matrix & $\begin{array}{c}\text { Tensile } \\
\text { strength }(\mathrm{MPa})\end{array}$ & $\begin{array}{l}\text { Tensile } \\
\text { Modulus } \\
(\mathrm{GPa})\end{array}$ & $\begin{array}{l}\text { Flexural } \\
\text { strength } \\
(\mathrm{MPa})\end{array}$ & $\begin{array}{l}\text { Flexural } \\
\text { modulus } \\
(\mathrm{GPa})\end{array}$ & $\begin{array}{l}\text { Impact Strength } \\
\qquad(\mathrm{J} / \mathrm{m})\end{array}$ & Ref \\
\hline $\begin{array}{l}\text { Indian Balcooa } \\
\text { Bamboo }\end{array}$ & $\begin{array}{c}\mathrm{PP}+\mathrm{MA}-\mathrm{g} \\
\mathrm{PP}\end{array}$ & $\begin{array}{l}24.50-28.95 \\
24.50-50.26\end{array}$ & $\begin{array}{c}0.560-1.633 \\
0.560-1.776\end{array}$ & $\begin{array}{l}38-68.85 \\
38-49.56\end{array}$ & $\begin{array}{l}1.650-4.127 \\
1.650-3.307\end{array}$ & $\begin{array}{l}26.54-38.92 \\
26.54-27.54\end{array}$ & [17] \\
\hline Bamboo & $\begin{array}{l}\text { Epoxy } \\
\text { Polyester }\end{array}$ & $\begin{array}{l}135 \\
126\end{array}$ & $\begin{array}{l}8.204 \\
5.515\end{array}$ & $\begin{array}{c}149 \\
161\end{array}$ & $\begin{array}{c}9.5 \\
9.612\end{array}$ & - & [50] \\
\hline $\begin{array}{l}\text { Bamboo } \\
\text { (Without alkali) }\end{array}$ & $\begin{array}{l}\text { Polyester } \\
\text { Epoxy }\end{array}$ & $\begin{array}{l}74 \\
86\end{array}$ & $\begin{array}{c}4.2 \\
6.736\end{array}$ & $\begin{array}{l}107 \\
119\end{array}$ & $\begin{array}{l}4.373 \\
11.9\end{array}$ & - & \\
\hline $\begin{array}{l}\text { Bamboo } \\
\text { (acrylonitrile, } \\
\text { 1h) }\end{array}$ & $\begin{array}{l}\text { Polyester } \\
\text { Epoxy }\end{array}$ & $\begin{array}{c}97 \\
125\end{array}$ & 9.9 & $\begin{array}{r}79 \\
133\end{array}$ & $\begin{array}{l}4.2 \\
6.6\end{array}$ & - & [21] \\
\hline $\begin{array}{l}\text { Bamboo } \\
\text { (acrylonitrile,5h } \\
\text { ) }\end{array}$ & $\begin{array}{l}\text { Polyester } \\
\text { Epoxy }\end{array}$ & $\begin{array}{c}84 \\
102\end{array}$ & $\begin{array}{l}5.8 \\
9.9\end{array}$ & $\begin{array}{c}78 \\
121\end{array}$ & $\begin{array}{l}2.5 \\
5.8\end{array}$ & - & \\
\hline Bamboo & $\begin{array}{l}\text { Polyester } \\
\text { Vinyl Ester }\end{array}$ & - & - & $\begin{array}{l}30.6-41.1 \\
44.9-55.1\end{array}$ & $\begin{array}{l}3.3-4.2 \\
3.2-3.6\end{array}$ & $\begin{array}{l}- \\
-\end{array}$ & \\
\hline Bamboo & HDPE & $18.58-25.47$ & $0.33-2.26$ & $22.75-27.86$ & $1.16-2.987$ & $51.21-71.24$ & \\
\hline $\begin{array}{l}\text { Bamboo } \\
\text { (Vf 30\%wt) }\end{array}$ & $\begin{array}{c}\mathrm{PP} \\
\mathrm{PP}+\mathrm{MA} 3 \%\end{array}$ & $\begin{array}{l}43.96 \\
48.50\end{array}$ & $\begin{array}{l}1.24 \\
1.425\end{array}$ & $\begin{array}{l}45.42 \\
54.26\end{array}$ & $\begin{array}{l}1.920 \\
2.096\end{array}$ & $\begin{array}{c}53.6 \\
59.50\end{array}$ & \\
\hline $\begin{array}{l}\text { Bamboo } \\
\text { (Vf 68\%wt) }\end{array}$ & Polyester & $101.8+/-2.8$ & - & $108.8+/-6.4$ & $8.2+/-1.8$ & - & \\
\hline $\begin{array}{l}\text { Bamboo } \\
\text { (with alkaline } \\
\text { treatment, Vf } \\
69 \% \text { wt) }\end{array}$ & Polyester & $112.2+/-2.2$ & - & $132.4+/-3.2$ & $9.8+/-2.4$ & - & \\
\hline $\begin{array}{l}\text { Bamboo } \\
\text { (Vf 60\%wt) }\end{array}$ & Epoxy & $112.8+/-1.4$ & - & $118.5+/-1.5$ & $7.8+/-3.8$ & - & [52] \\
\hline $\begin{array}{l}\text { Bamboo } \\
\text { (With alkaline } \\
\text { treatment, Vf } \\
60 \% \text { wt) }\end{array}$ & Epoxy & $144.8+/-0.7$ & - & $162.1+/-2.8$ & $8.2+/-2.1$ & - & \\
\hline Fiber & Type of matrix & $\begin{array}{l}\text { Tensile } \\
\text { strength } \\
(\mathrm{MPa})\end{array}$ & $\begin{array}{l}\text { Tensile } \\
\text { Modulus } \\
(\mathrm{GPa})\end{array}$ & $\begin{array}{l}\text { Flexural } \\
\text { strength } \\
(\mathrm{MPa})\end{array}$ & $\begin{array}{l}\text { Flexural } \\
\text { modulus } \\
(\mathrm{GPa})\end{array}$ & $\begin{array}{l}\text { Impact } \\
\text { Strength } \\
(\mathrm{J} / \mathrm{m})\end{array}$ & Ref \\
\hline $\begin{array}{l}\text { Bamboo } \\
(10 \%, 20 \%, \\
30 \%)\end{array}$ & Polypropylene & $30.77-41.35$ & $1.89-2.82$ & $69.93-93.63$ & $6.03-10.66$ & $34.03-57.78$ & [46] \\
\hline Bamboo & Epoxy & 26.417 & 2.48 & - & - & - & {$[53]$} \\
\hline $\begin{array}{l}\text { Bamboo: Flax } \\
\text { Vf(0,10,20,30,4 } \\
\text { 0)\%wt }\end{array}$ & Epoxy & $23.45-34.27$ & - & $58.11-89.60$ & - & $1.25-2.35$ & [49] \\
\hline $\begin{array}{l}\text { Bamboo } \\
\text { (Fiber Diameter: } \\
0.2,0.3,0.4) \mathrm{mm}\end{array}$ & Epoxy & $30.11-32.05$ & $3.344-3.346$ & - & - & - & {$[54]$} \\
\hline $\begin{array}{l}\text { Bamboo } \\
(\operatorname{Vf}(60,70) \%)\end{array}$ & Polypropylene & - & - & $11.67-19.15$ & $3.05-3.13$ & - & [55] \\
\hline Bamboo & $\mathrm{PP}+\mathrm{MA}$ & $35.1+/-2.42$ & $4.69+/-0.55$ & & & & [29] \\
\hline $\begin{array}{l}\text { Bamboo } \\
\text { (Vf 57\%) }\end{array}$ & Epoxy & $392+/-8.51$ & $29+/-1,25$ & $226+/-25.13$ & $19+/-1.32$ & - & {$[56]$} \\
\hline Bamboo & Epoxy & 43.47 & 6.63 & 60.97 & 3.2 & - & {$[51]$} \\
\hline $\mathrm{Ci}$ bamboo & Phenolic & $16.43-20.30$ & $1.48-1.68$ & - & - & - & {$[57]$} \\
\hline
\end{tabular}


Martijanti et al., International Journal of Emerging Trends in Engineering Research, 8(6), June 2020, 2346 - 2359

\begin{tabular}{llll}
$\begin{array}{l}\text { (Neosinocalamus } \\
\text { affinins) }\end{array}$ & & & \\
$\begin{array}{l}\text { Short Fiber } \\
\text { Bamboo }\end{array}$ & Phenolic & 29.9 & 2.92 \\
$\begin{array}{l}\text { Short Fiber } \\
\text { Bamboo }\end{array}$ & Epoxy & 36.1 & 3.26 \\
$\begin{array}{l}\text { Long Fiber } \\
\text { Bamboo }\end{array}$ & Epoxy & 203 & 51 \\
$\begin{array}{l}\text { Laminated } \\
\text { Bamboo }\end{array}$ & Phenolic & 114.4 & - \\
\hline
\end{tabular}

Note: PP = polypropylene, HDPE = High Density Polyethylene, MA=Maleic Anhydride

Other studies that analyze the characteristics of bamboo-reinforced composite material with varied parameters are the type of matrix to the strength of the composite material. The type of matrix will affect the mechanical properties of bamboo fiber-reinforced composite materials. This process has been carried out by researchers. The effect of matrix type on tensile strength, tensile modulus, flexural strength, Flexural modulus, and impact strength can be seen in Table 7 [17,21]. Resume of the study on the effect of matrix type to mechanical characteristics of bamboo fiber composites can seen in table 7 .

\subsection{Application of Bamboo Fiber Composite Materials}

Utilization of bamboo material for various purposes has been done since long time ago for household purposes such as containers, chopsticks, woven mats, fishing rods, handicrafts, and furniture. In addition, bamboo has been widely used in building applications, such as floors, ceilings, walls, windows, doors, fences, residential roofs, trusses, rafters and purlin. Bamboo is even used in construction as structural materials for bridges, water transportation facilities and ceiling. By paying attention to the high strength of bamboo and supported by the fact that high quality bamboo can be obtained at the age of 2 to 5 years old, a relatively short period of time, and considering that bamboo is easy to plant, and does not require a special care, then bamboo has a big opportunity to replace wood [4].

Bamboo fiber composite material has been used in producing a prototype (inner board of trunk door panel) by Mitsubishi Japan. They use polybutylene resin to develop the prototype. This product was developed by Mitsubishi to reduce the cost of producing materials used today and $\mathrm{CO} 2$ emissions [58]. Other material research are also found in various applications [59-61]. Extensive changes from an economic perspective are needed in an advance composite; the only choice is the use of natural plant fibers. Bamboo can serve as an excellent source to replace the existing crisis, namely the cost and availability of raw materials.

\section{CONCLUSION}

Bamboo fiber is discussed in the results of a journal review, from bamboo that grows in Asia, especially China, India and Indonesia. Bamboo fiber is one of the natural fibers that can be used as raw material for natural fibers, considered from the advantages of bamboo fiber compared to glass fiber that has a low cost aspect, abundant raw materials, environmentally friendly, light specific gravity, high growth rate, good strength and stiffness value. Bamboo fiber consists of cellulose, hemicellulose and lignin. The level of cellulose and hemicellulose in the form of holocellulose can be more than $50 \%$.

Fiber processing methods can be carried out chemically, mechanically and combination of both. Fiber processing carried out by an alkaline process will have a positive impact on the strength of the bamboo fiber composite material. Steam explosion method (Steam explosion) is one of the effective methods to produce bamboo fiber with good quality in terms of strength.

The characteristics of bamboo fiber composite materials (mechanical and physical properties) will be affected by the parameters of composite materials production process, namely the choice of fiber type, matrix type, fiber orientation, fiber volume fraction, fiber size, fiber orientation, fiber shape, and composite fabrication parameters (types of process, temperature, pressure, time).

During this time, the benefits bamboo have been used since long time ago for household purposes such as containers, chopsticks, woven mats, fishing rods, handicrafts, and furniture. Besides bamboo has also been widely used in building applications, such as floors, ceilings, walls, windows, doors, fences, residential roofs, trusses, rafters and purlin. Bamboo is even used in construction as structural materials for bridges, water transportation facilities and ceiling.

Scientists around the world have conducted various studies with new ideas to provide basic support for works and also employ the community. Current research on bamboo fiber based composites uses the basic and applied science in terms of modification, mechano-physical, thermal and other properties. The final goal is to utilize bamboo fiber that has been far behind the projected target, especially in Malaysia, although other countries such as India and China have moved a long way forward in utilizing bamboo fiber in a socio-economic sense. The sustainable future of the 
bamboo-based composite industry will help in utilizing bamboo in ways other than traditional modes.

Effective characterization of bamboo fiber and bamboo fiber-based composites must be more advanced in terms of analysis and testing. In this review article, researchers have tried to gather information about the analysis and testing methods used. However, scientists have conducted a lot of studies on bamboo-based composites, but they are still required to conduct more researches and innovation in this area (especially Indonesia) to overcome potential challenges in the future. These things will make life easier for urban and rural communities who are more dependent on synthetic-based composites.

\section{REFERENCES}

1. M, Ramesha, K. Palanikumar, \& K. H. Reddy, (2017) Plant fibre based bio-composites: Sustainable and renewable green materials, Renewable and Sustainable Energy Reviews 79 ,2017,pp. 558-584. https://doi.org/10.1016/j.rser.2017.05.094

2. F. A. McClure, (1996).Bamboos. A Fresh Perspective. Harvard University Press, Cambridge, Mas, USA,347p

3. W. Liese, (1985). Anatomy of Bamboo Proceedings Workshop Bamboo Research in Asia. Singapore 28-30 May 1980. International Development Research Center. Ottawa.

4. H. A. Khalil, I. U. H. Bhat, M. Jawaid, A. Zaidon, D. Hermawan, \& Y. S. Hadi, (2012). Bamboo fibre reinforced biocomposites: A review. Materials \& Design, 42, 353-368. https://doi.org/10.1016/j.matdes.2012.06.015

5. Dransfield, Soejatmi, and E. A. Widjaja, Plant resources of South-East Asia. Vol. 7. Pudoc, 1995.

6. W. Liese, (1980). Anatomy of Bamboo. Bamboo Reasearch in Asia. Proceedings of a Workshop Singapore: International Development Research Center and the International Union of Forestry Research Organizations. hlm 161-164.

7. A. Sulthoni, (1994).Permasalahan Sumberdaya Bambu di Indonesia. Dalam Strategi Penelitian Bambu Indonesia", hal : 30-36.

8. A. Martawijaya, (1997).Protection of Freshout Logs Againts Ambrosia Beetle Attack In Kalimantan. Eight Wortd Forestry Congress, Jakarta.

9. F. A. McClure, (1953). Bamboo as Building Material.Washington

DC,Construction and Building Materials, vol.20, pp. 648-656.

10. Badan Pusat Statistik [BPS].Jakarta. (2004). Pusat Inventarisasi dan Statistik Kehutanan \& Direktorat Statistik Pertanian. BPS.

11. U. C. Jindal, (1986). Development and testing of bamboofibres reinforced plastic Composites. $J$ Compos Mater, vol. 20, pp.19-29.

https://doi.org/10.1177/002199838602000102
12. M. N. Rian̄o, X. Londoño, Y. López, \& J. H. Gómez, (2002). Plant growth and biomass distribution on Guadua angustifolia Kunth in relation to ageing in the Valle del Cauca-Colombia. Bamboo Science and Culture: The Journal of the American Bamboo Society, 16(1), 43-51.

13. L. Nayak, \&.S. P. Mishra, (2016). Prospect of bambu as a renewable textile fiber, historical, overview labeling controversies and regulation. Fashion and Textile 3 (2), 1- 23. 4598-4604.

14. J. Seema, \& K. Rakesh, (1992). Mechanical behaviour of bamboo and bamboo composite. Journal of Material Science, vol. 27, Issue 17, pp 4598-4604.

15. N. T. Phong, T. Fujii, B. Chuong, \& K. Okubo, (2012).Study on How to Effectively Extract Bamboo Fibers from Raw Bamboo and Wastewater Treatment. Journal of Materials Science Research, vol. 1. https://doi.org/10.5539/jmsr.v1n1p144

16. E. Trujillo, M. Moesen, L. Osorio, A. W. V. Vuure, J. Ivens, \& I. Verpoest, (2014). Bamboo fibres for reinforcement in composite materials: Strength Weibull analysis. Composite Part A: Appl Sci Manuf, vol.61, pp.115-25.

17. V. Kaur, D. P. Chattopadhyay, \& S. Kaur, (2013). Study on extraction ofbamboo fibres from raw bamboo fibres bundles using different retting techniques, Text Light Ind Sci Technol, vol. 2, pp. 174-179.

18. J.He. Y. Xin Tang, \& S. Y. Wang (2007) Differences in morphological characteristics of bamboo fibres and other natural cellulose fibres: Studies on X-ray diffraction, solid state 13C-CP/MAS NMR, and second derivative FTIR spectroscopy data." (2007): 807-818.

19. H. Kim, K. Okubo, T. Fujii, \& K. Takemura, (2013). Influence of fiber extraction and surface modification on mechanical properties of green composites with bamboo fiber. J Adhes Sci Technol, vol. 27, pp. 1348-1358. https://doi.org/10.1080/01694243.2012.697363

20. V. Choudhary, \& R. Kumar, (2010). Study on the compatibility of unbleached and bleached bamboo-fiber with LLDPE matrix. J Therm Anal Calorim, vol. 102, pp. 751-761.

21. H. Takagi, \& Y. Ichihara, (2004). Effect of fiber length on mechanical properties of "Green ${ }^{e e}$ composites using a starch-based resin and short bamboo fibers. JSME Int J Ser A, vol. 47, pp. 551-555.

22. P. K. Kushwaha, \& R. Kumar, (2010). Studies on performance of acrylonitrile pretreated bamboo reinforced thermosetting resin composites. J Reinf Plast Compos, vol. 29, pp. 1347-1352. https://doi.org/10.1177/0731684409103701

23. K. Okubo, T. Fujii, \& Y. Yamamoto, (2004). Development of bamboo-based polymer composites and their mechanical properties. Composite : Part A: Appl Sci Manuf, vol. 35, pp. 377-383. 
Martijanti et al., International Journal of Emerging Trends in Engineering Research, 8(6), June 2020, 2346 - 2359

24. N. H. Tung, H. Yamamoto, T. Matsuoka, \& T. Fujii, (2004). Effect of surface treatment on interfacial strength between bamboo fiber and PP resin. JSME Int J Ser A, vol. 47, pp. 561-565.

25. M. Ashimori, T. Katayama, E. Aoyama, \& S. Nagai, (2004). Study on splittingof bamboo fibers due to freezing and tensile strength of FRTP using bamboo fibers. JSME Int J Ser A, vol. 47, pp. 566-569. https://doi.org/10.1299/jsmea.47.566

26. W. Tatang, K. Cica, \& S. Doni, (2015).Extraction of Fiber From Bamboo (Gigantochloa Apus) for Raw Material of Creative Industry. Arena Tekstil, vol. 30 No. 2, pp: 95-102.

27. M. M. Thwe, \& K. Liao, (2002). Effects of environmental aging on the mechanicalproperties of bamboo - glass fiber reinforced polymer matrix hybrid composites. Composite Part A: Appl Sci Manuf, vol. 33, pp.43-52.

28. G. Han, Y. Lei, Q. Wu, Y. Kojima, \& S. Suzuki, (2008). Bamboo-fiber filled high density polyethylene composites: effect of coupling treatment and nanoclay. Journal of Polymers and the Environment, 16(2), 123-130.

29. F. G. Shin, X. J. Xian, W. P. Zheng, \& M. W. Yipp, (1989). Analyses of the mechanical properties and microstructure of bamboo-epoxy composites. Journal of Materials Science, 24(10), 3483-3490.

https://doi.org/10.1007/BF02385729

30. Rao, K. M. Mohan, and K. M. Rao, Extraction and tensile properties of natural fibers: Vakka, date and bamboo. Composite structures 77.3 (2007): 288-295.

31. N. T. Phong, T. Fujii, B. Chuong, \& K. Okubo, (2012). Study on how to effectively extract bamboo fibers from raw bamboo and wastewater treatment. Journal of Materials Science Research, 1(1), 144.

32. Deshpande, P. Abhijit, M. B. Rao, \& C. L. Rao, Extraction of bamboo fibers and their use as reinforcement in polymeric composites. Journal of applied polymer science 76.1 (2000): 83-92.

33. D. Fengel, X. Shao, \& Munchen, (1984). Chemical and ultrastructural study of the Bamboospecies Phyllostachysmakinoi Hay. Wood Sci Technol, vol. 112, pp.103-112.

34. S. Shao, G. Wen, \& Z. Jin, (2008). Changes in chemical characteristics of bamboo (Phyllostachyspubescens) components during steam explosion. Wood Sci Technol, vol. 42, pp. 439-451.

35. Y. C. Zang, W. H.Yan, \& Q. Y. Ping, (2010). Morphology and properties of hybrid composites based on polypropylene/polylactic acid blend and bamboo fiber. Bioresource Technology, 101(20), 7944-7950.

https://doi.org/10.1016/j.biortech.2010.05.007

36. M. Abdelmouleh, S. Boufis, M. N. Belgacem, \& A. Dufresne, (2007). Short Natural-Fibre Reinforced Polyethylene and Natural Rubber Composites: Effect of Silane Coupling Agents and Fibre Loading. Composite Science and Technology, 67(7-8), 1627-1639.

37. G. B. Gaceva, M. Avella, M. Malinconico, A. Buzarovska, A. Grozdanov, G. Gentile, \& M. E. Errico, (2007). Natural Fiber Eco- Composites Polymer Composites Wiley InterScience Society of Plastics Engineers 28 98-107

38. C. S. Verma, \& V. M. Charia, (2012). Development of layered laminate bamboo composite and their mechanical properties. Composites: Part B, Vol. 43, pp. 1063-1069.

39. C. S. Verma, \& V. M. Chariar, (2013). Stiffness and strength analysis of four layered laminate bamboo composite. Composites: Part B, Vol. 45, pp. 369-376.

40. H. Wang, R. Chang, K. C. Sheng, M. Adl, \& X. Q. Qian, (2008). Impact response of bamboo-plastic composites with the properties of bamboo and polyvinylchloride (PVC). Journal of Bionic Engineering, 5(1), 28-33. https://doi.org/10.1016/S1672-6529(08)60068-2

41. O. Shinji, (2012). Tensile Properties of Bamboo Fiber Reinforced Biodegradable Plastics. International Journal of Composite Materials, pp. 1-4

42. H. Kabir, M. A. Gafur, F. Ahmed, F. Begum, \& M. R. Qadir, (2014). Investigation of physical and mechanical properties of bamboo fiber and PVC foam sheet composites. Universal Journal of Materials Science, 2(6), 119-124.

43. S. sreenivasulu, \& A. C. Reddy, (2014). Mechanical Properties Evalution of Bamboo Fiber Reinforced Composite Materials. International Journal of Engineering Research, vol 3 Issue No: Special 1, pp: 187-194.

44. A. I. Al-Mosawi, S. A. Abdulsada, \& A. Hashim, Mechanical properties of recycled bamboo fibers reinforced composite. European Journal of Advances in Engineering and Technology 2.4 (2015): 20-22

45. C. Shih-Hsuan, I. Ivan, W. Cheng-Lung, \& C. Kun-Ting, (2016). Mechanical properties of urethane diacrylate/bamboo powder composite fabricated by rapid prototyping system. Rapid Prototyping Journal.Vol 22 , Number 4, pp. 676-683.

46. B. Kishor, \& P. Sanjay, (2016). Bamboo Fibre-reinforced Self-compatibilizing Functionalized Polypropylene Composites by Palsule Process. Polymers \& Polymer Composites, Vol. 24, No. 8, pp. 663-673.

47. N. Z. Mahmud, Z. K Jayaraman, \& R. J. T. Lin, (2016). Mechanical, Thermal and Instrumented Impact Properties of Bamboo Fabric-Reinforced Polypropylene Composites. Polymers \& Polymer Composites, Vol. 24, No. 9. https://doi.org/10.1177/096739111602400912

48. M. Ramachandran, B. Sahas, \& R. Pramod, (2016). Experimental study of bamboo using bananaand linen fibre reinforced polymericcomposites., Perspectives in Science, vol. 8, pp. 313-316 
49. S. Sathish, K. Kumaresan, L. Prabhu, \& N. Vigneshkumar, (2017). Experimental Investigation on Volume Fraction of Mechanical and Physical Properties of Flax and Bamboo Fibers Reinforced Hybrid Epoxy Composites. Polymers \& Polymer Composites, Vol. 25, No. 3, 2017,pp. 229-235.

50. P. K. Kushwaha, \& R. Kumar, (2015). The studies on performance of epoxy and polyester based composites reinforced with bamboo and glass fibers. J Reinf Plast Compos, vol. 29, pp. 1952- 1962.

51. Sutanu, S., ,M. Muralidharb. ,Thingujam, J., S., , S, Sarkard. (2015). Characterization of mechanical properties of hybrid bamboo/GFRP and jute/GFRP composites . Today: Proceedings 2, pp. 1398 - 1405 https://doi.org/10.1016/j.matpr.2015.07.059

52. S. Mohini, \& V. S. Gowri, (2003). Studies on Bamboo Polymer Composites With Polyester Amid Polyol as Interfacial Agent. Polymer Composites, vol 24, pp. 428-436.

53. R. S. Wani, \& R. R. Shitole, (2017). Tensile Testing of Bamboo Fiber Reinforced Epoxy Composite. IOSR Journal of Mechanical and Civil Engineering (IOSR-JMCE), e-ISSN: 2278-1684,p-ISSN: 2320-334X,pp. 07-11

54. Z. Khan, B. F. Yousif, \& M. Islam, (2017). Fracture behaviour of bamboo fiber reinforced epoxy composites. Composites Part B: Engineering, 116, 186-199.

55. H. Shah, R. Narendra,\& Y. Yiqi, (2012). Ultra-light-weight composites from bamboo strips and polypropylene web with exceptional flexural properties. Composites: Part B, vol 43, pp. 1658-1664.

56. Subhankar, B., Sweety, S., M., H.,\& Qumrul, A. (2011). Physical, Mechanical and Thermal Properties of Jute and Bamboo Fiber Reinforced Unidirectional Epoxy
Composites. Materials and Design, vol. 32, pp. 4658-4663.

57. Y. L. Yu, X. A. Huang, \& W. J. Yu, (2014). High performance of bamboo $\square$ based fiber composites from long bamboo fiber bundles and phenolic resins. Journal of Applied Polymer Science, 131(12). https://doi.org/10.1002/app.40371

58. S. Keiichiro, \& K. Teruo, (2010). Trend of natural fiber reinforced plastic for automobile industry in Germany and Japan. Proceeding of The Sixth international Workshop on Green Composites (IWGC-6), pp.109-112

59. A. Hazim, A. Hashim and H. M. Abduljalil (2019). Novel (PMMA-ZrO2-Ag) Nanocomposites: Structural, Electronic, Optical Properties as Antibacterial for Dental Industries, International Journal of Emerging Trends in Engineering Research, $7(8), 68-84$ https://doi.org/10.30534/ijeter/2019/01782019

60. A. Hazim, H. M. Abduljalil and A. Hashim (2019). Structural, Electronic, Optical Properties and Antibacterial Application of Novel (PMMA-Al203-Ag) Nanocomposites for Dental Industries Applications, International Journal of Emerging Trends in Engineering Research 7(8), 104 122. https://doi.org/10.30534/ijeter/2019/04782019

61. E. Julianto, W.A. Siswanto and M. Effendy (2019) Characteristics of Temperature changes and Stress of Float Glass under Heat Radiation, International Journal of Emerging Trends in Engineering Research 7(8), $228-233$ https://doi.org/10.30534/ijeter/2019/03792019 